\title{
Chromium distribution in shoots of macrophyte Callitriche cophocarpa Sendtn.
}

\author{
Joanna Augustynowicz • Paweł Wróbel • \\ Bartosz J. Płachno • Grzegorz Tylko • \\ Zbigniew Gajewski · Dariusz Węgrzynek
}

Received: 20 December 2013 / Accepted: 7 February 2014 / Published online: 5 March 2014

(c) The Author(s) 2014. This article is published with open access at Springerlink.com

\begin{abstract}
The aim of the study was the analysis of $\mathrm{Cr}$ distribution in shoots of the macrophyte Callitriche cophocarpa by means of two X-ray-based techniques: micro X-ray fluorescence ( $\mu \mathrm{XRF}$ ) and electron probe $\mathrm{X}$-ray microanalysis (EPXMA). Plants were treated with $100 \mu \mathrm{M}\left(5.2 \mathrm{mg} \mathrm{l}^{-1}\right)$ chromium solutions for 7 days. $\mathrm{Cr}$ was introduced independently at two speciations as $\mathrm{Cr}(\mathrm{III})$ and $\mathrm{Cr}(\mathrm{VI})$, known for their diverse physicochemical properties and different influence on living organisms. A comparative analysis of $\mathrm{Cr}(\mathrm{III})$-treated plants by EPXMA and $\mu$ XRF demonstrated high deposition of $\mathrm{Cr}$ in epidermal glands/hairs localized on leaves and stems of the plant shoots. $\mathrm{Cr}$ in $\mathrm{Cr}(\mathrm{III})$-treated plants was recorded solely in glands/hairs, and the element was not present in any other structures. On the other hand, $\mathrm{Cr}$ in $\mathrm{Cr}(\mathrm{VI})$-treated group
\end{abstract}

J. Augustynowicz $(\bowtie) \cdot$ Z. Gajewski

Unit of Botany and Plant Physiology, Faculty of Horticulture, Institute of Plant Biology and Biotechnology, University of Agriculture in Kraków, al. 29 Listopada 54, 31-425 Kraków, Poland

e-mail: augustyn@ogr.ur.krakow.pl

P. Wróbel · D. Węgrzynek

Department of Medical Physics and Biophysics, Faculty of Physics and Applied Computer Science, AGH University of Science and Technology, al. Mickiewicza 30, 30-059 Kraków, Poland

\section{B. J. Płachno}

Department of Plant Cytology and Embryology, Faculty of Biology and Earth Sciences, Institute of Botany, Jagiellonian University, Gronostajowa 9, 30-387 Kraków, Poland

\section{G. Tylko}

Department of Cell Biology and Imaging, Faculty of Biology and Earth Sciences, Institute of Zoology, Jagiellonian University, Gronostajowa 9, 30-387 Kraków, Poland of plants was rather found in vascular bundles. Moreover, the concentration of $\mathrm{Cr}$ in $\mathrm{Cr}(\mathrm{VI})$-treated plants was significantly lower than in plants incubated in $\mathrm{Cr}$ (III) solution. The results obtained in this work suggest differences in chromium uptake, transport and accumulation dependent on the oxidative state of the element.

Keywords Callitriche $\cdot$ Chromium · EPXMA · Glands · Macrophytes $\cdot$ X-ray

\section{Introduction}

Excess of heavy metal ions in plant environment has a negative impact on the plant metabolism at different levels of plant functioning. In contrast to terrestrial plants, mechanisms related to the uptake or accumulation of heavy metal ions by aquatic ones are far less known. Due to the water environment of aquatic vascular plants (macrophytes), the availability of heavy metal compounds to their cells or tissues is much higher than in the case of terrestrial vegetation. Aquatic plants obtain minerals from both aquatic and sediment reservoirs. The uptake of metallic compounds by macrophytes depends on the chemical form of ions, and on the life form of particular plants: floating, emergent, submersed, well rooted or rootless (Malec et al. 2011). In the group of aquatic species, there are macrophytes that efficiently remove $\mathrm{Cr}$ contaminants, e.g.: Eicchornia crassipes, Polygonum hydropiperoides, Nymphaea spontanea, and Leersia hexandra (Choo et al. 2006; Qian et al. 1999; Zayed and Terry 2003; Zhang et al. 2007). Similarly to terrestrial plants, the $\mathrm{Cr}$ levels in shoots of aquatic species are in most cases lower than in roots, since root-shoot translocation of $\mathrm{Cr}$ is limited (Zayed and Terry 2003). For example, in the case of Borreria scabiosoides treated with 
$\mathrm{Cr}(\mathrm{III})$, the element is preferentially accumulated in cell walls and in some vacuoles of cortical parenchyma (Mangabeira et al. 2006). Moreover, species submersed in water may have a higher accumulating potential than floating or emergent ones due to the increased contact area with the surrounding environment (Rai et al. 1995). Thus, these species are of great interest for phytoremediation purposes.

In previous studies, we discovered the unusual ability of Callitriche cophocarpa Sendtn. to extract $\mathrm{Cr}$ from water solutions when the ions of the element were at $\mathrm{Cr}(\mathrm{VI})$ and $\mathrm{Cr}$ (III) oxidation states (Augustynowicz et al. 2010, 2013b). Callitriche cophocarpa belongs to the genus Callitriche (water starworts) that consists of about 50 globally distributed species, classified to the Callitrichaceae family. Species of Callitriche are aquatic, amphibious or terrestrial (Erbar and Leins 2004). The submersed C. cophocarpa is one of the most common Callitriche species in Europe (Schotsman 1972). Similarly to other species of the Callitriche genus, this plant is interesting due to its geitonogamy - a unique self-fertilization system (Philbrick and Bernardello 1992) and the potential utility of C. cophocarpa in phytoremediation of aquatic reservoirs (Favas et al. 2012; Pratas et al. 2010, 2012).

$\mathrm{Cr}(\mathrm{VI})$ and $\mathrm{Cr}(\mathrm{III})$ forms are the most stable and common in the environment. The main source of chromium relates to anthropogenic activity (e.g., metal and alloy manufacturing, brick lining, chrome plating, production of pigments and leather tanning), since the erosion of $\mathrm{Cr}-$ rich rocks is relatively low (Kabata-Pendias and Mukherjee 2007). $\mathrm{Cr}(\mathrm{VI})$ and $\mathrm{Cr}(\mathrm{III})$ differ in their physiochemical properties and, in consequence, in activities related to living organisms. Although $\mathrm{Cr}(\mathrm{III})$ at low concentrations is an essential microelement necessary for the glucose metabolism in mammals, its function in plants is not clear. $\mathrm{Cr}(\mathrm{VI})$, however, is a strong oxidizing agent toxic to biota (Saha et al. 2011; Zayed and Terry 2003). In aquatic systems, the levels of both speciations are often significantly over-limited (Kyzioł-Komosińska and Kukułka 2008) being harmful to aquatic life. Therefore, $\mathrm{Cr}(\mathrm{VI})$ and $\mathrm{Cr}(\mathrm{III})$ are treated by the Environmental Protection Agency (USA) as prioritytoxic pollutants.

The concentration of $\mathrm{Cr}$ ions used in the present study induced some stress symptoms to C. cophocarpa, but did not cause serious physiological disorders (Augustynowicz et al. 2010, 2013b). Still, it was more than a hundred times higher than the concentration of $\mathrm{Cr}$ acceptable by Polish Ministry of the Environment regulations (Regulation, 9th of Nov 2011). The experimental conditions were environmentally relevant in the case of medium composition-filtered water from natural $C$. cophocarpa habitat and light intensity.

The objective of this work was to determine the distribution of chromium in leaves and stems of submersed macrophyte $C$. cophocarpa when $\mathrm{Cr}$ was administrated to plant environment as either $\mathrm{Cr}(\mathrm{VI})$ or $\mathrm{Cr}(\mathrm{III})$ forms. The distribution of the element was analyzed by means of two $\mathrm{X}$-ray fluorescence-based methods. Micro X-ray fluorescence $(\mu \mathrm{XRF})$ spectroscopy was used to determine the pattern of $\mathrm{Cr}$ accumulation in micrometer scale, whereas $\mathrm{X}$-ray microanalysis combined with scanning electron microscopy (electron probe X-ray microanalysis; EPXMA) revealed submicrometer $\mathrm{Cr}$ distribution. Micro X-ray fluorescence is a non-destructive technique that allows studies of elements with a very narrow beam of X-rays at concentration levels in $\mu \mathrm{g} \mathrm{g}^{-1}$ range (for review see Punshon et al. 2009). Electron probe X-ray microanalysis, however, enables elemental analysis with much higher level of detection $\left(\mathrm{mg} \mathrm{g}^{-1}\right)$, but gives the possibility of concomitant observation of specimen morphology (Goldstein et al. 2003). Until now, there were no available data dealing with chromium distribution in plants of the Callitriche genus. The obtained results will contribute to the knowledge concerning organ/ tissue structures responsible for element uptake by aquatic phytoremediators.

\section{Materials and methods}

Plant material and incubation in $\mathrm{Cr}$ media

Callitriche cophocarpa was collected from the Dłubnia river, Southern Poland $\left(50^{\circ} 16^{\prime} \mathrm{N} / 19^{\circ} 56^{\prime} \mathrm{E}\right)$, during the vegetation season of 2012. Mature shoots about $10 \mathrm{~cm}$ long were rinsed with tap water several times followed by three times rinsing in distilled water. $\mathrm{The} \mathrm{Cr}$ solutions were prepared using water derived from the natural environment of plants. River water was filtered (Supelco filters, $0.2 \mu \mathrm{m}$ pore size) to prevent growth of microorganisms. The chemical composition of water was analyzed by means of inductively coupled plasma mass spectrometry (ICP-MS; ELAN 6100, Perkin Elmer, Waltham, MA, USA) (PN-EN ISO 9963-1:2001) and titration methods (PN-ISO 9297:1994, PN-EN ISO 17294-1:2007). The quantitative results were obtained with ICP multi-element standard (Merck). The concentrations of ions $\left(\mathrm{mg} \mathrm{l}^{-1}\right)$ present in water were the following: $4.24 \mathrm{Na}^{+}, 1.75 \mathrm{~K}^{+}, 69.65 \mathrm{Ca}^{2+}, 5.01 \mathrm{Mg}^{2+}$, $2 \cdot 10^{-3} \mathrm{Fe}^{2+}, 5 \cdot 10^{-3} \mathrm{Mn}^{2+}, 5 \cdot 10^{-3} \mathrm{Zn}^{2+}, 6 \cdot 10^{-4} \mathrm{Cu}^{2+}, 10^{-3}$ $\mathrm{Mo}^{6+}, 16.50 \mathrm{Cl}^{-}, 10.20 \mathrm{SO}_{4}{ }^{2-}, 189.00 \mathrm{HCO}_{3}{ }^{2-}, 13.50$ $\mathrm{NO}_{3}{ }^{2-}, 0.15 \mathrm{PO}_{4}{ }^{3-}, 0.08 \mathrm{BO}_{3}{ }^{3-}$. The level of $\mathrm{Pb}, \mathrm{Hg}$, and $\mathrm{Cd}$ did not exceed $0.2 \mu \mathrm{g} \mathrm{l}^{-1}$ and $\mathrm{Cr}$ content was lower than $0.02 \mu \mathrm{g} \mathrm{l}^{-1}$. The electrical conductivity of water was equal to $0.335 \mathrm{mS} \mathrm{cm}^{-1}$, pH 7.8 and $\mathrm{Eh}=180 \mathrm{mV}$. The solutions containing $100 \mu \mathrm{M}\left(5.2 \mathrm{mg} \mathrm{l}^{-1}\right)$ of $\mathrm{Cr}(\mathrm{VI})$ or $\mathrm{Cr}(\mathrm{III})$ were prepared from $\mathrm{K}_{2} \mathrm{Cr}_{2} \mathrm{O}_{7}$ and $\mathrm{Cr}_{2}\left(\mathrm{SO}_{4}\right)_{3} 18 \mathrm{H}_{2} \mathrm{O}$, respectively (POCh Gliwice, Poland). $1.5 \mathrm{~g}$ of shoots were cultured in $300 \mathrm{ml}$ of the aforementioned $\mathrm{Cr}$ solutions or in the control 
solution (without $\mathrm{Cr}$ salts) for 7 days in the phytotron under the $16 \mathrm{~h}$ of light intensity at $35 \mu \mathrm{mol} \mathrm{m} \mathrm{m}^{-2} \mathrm{~s}^{-1}$ (LF $36 \mathrm{~W} / 54$, Piła, Poland) and $8 \mathrm{~h}$ of darkness, at $23^{\circ} \mathrm{C}$. The light intensity was comparable to the one detected in the natural $\mathrm{Cal}$ litriche environment. The analysis of chromium distribution was performed on mature leaves and stems.

\section{$\mu \mathrm{XRF}$ of chromium}

The plant samples were prepared according to a freezedrying protocol to avoid dehydration and redistribution of $\mathrm{Cr}$ ions during prolonged $\mu \mathrm{XRF}$ measurements. After treatment with $\mathrm{Cr}(\mathrm{VI})$ - and $\mathrm{Cr}(\mathrm{III})$-containing media, the shoots were thoroughly washed in distilled water, gently dried with filter paper to remove access of water and immediately plunged-frozen in liquid nitrogen. Then, the samples were transferred to lyophilizer chamber (Alpha 1-4 Martin Christ Gefriertrocknungsan-lagen $\mathrm{GmbH}$ lyophilizer, Germany) and left for $24 \mathrm{~h}$ at 1.03 mbar and $-20^{\circ} \mathrm{C}$. After drying, the temperature of the specimen holder was gradually increased to achieve room temperature and the plant samples removed. All specimens were finally mounted between two $2.5 \mu \mathrm{m}$ mylar films stretched on the plastic holder and positioned on the motorized stage of $\mu$ XRF machine.

Two-dimensional distribution maps of chromium or potassium (as a vascular bundle indicator) (Thompson and Zwieniecki 2005) were performed with a laboratory setup consisting of low-power X-ray tube (XOS, East Greenbush, USA) with molybdenum anode and SDD detector (Ketek, Munich, Germany) (Wróbel et al. 2012). The angle between the impinging beam and the sample normal was $45^{\circ}$ and the angle between detector axis and the sample normal was $45^{\circ}$. The X-ray tube voltage and current were $50 \mathrm{kV}$ and $1 \mathrm{~mA}$, respectively. Primary radiation from the $\mathrm{X}$-ray tube was focused with polycapillary lens into Gaussian-shaped beam (Węgrzynek et al. 2008). The size of the focal spot was $16.4 \mu \mathrm{m}$ at full width of half maximum and the size of irradiated area was $380 \mu \mathrm{m}^{2}$. The mapping of chromium was performed for the area of $1-1.5 \mathrm{~mm}^{2}$ with step size in $X-Y$ direction equal to $20 \mu \mathrm{m}$ and dwell-time $1-1.5 \mathrm{~s}$. The average time of imaging of single sample was $4.5 \mathrm{~h}$. Thus, the qualitative maps of $\mathrm{Cr}$ distribution obtained with $\mu$ XRF present X-ray intensity (count per second) recorded by SDD detector from irradiated area. The intensity of X-ray emission is proportional to element content. Three (control) or eight (Cr-treated samples) independent leaves and stems were mapped.

\section{EPXMA of chromium}

Leaves of C. cophocarpa were cut out from the stem, transferred to a drop of plant culture medium and divided into two parts perpendicularly to their long axis. Then, one group of leaf specimens was prepared for chromium analyses in their epidermal structures only-glands/hairs and stomata, whereas the second group was prepared for chromium investigation in mesophyll and vascular tissues. The specimens from the first group were gently dried with filter paper to remove excess of water and attached to aluminum specimen carriers (no. 16701950, Leica Microsystems, Germany) covered with a thin layer of tissue freezing medium (OCT Compound, Leica Microsystems, Germany). There, the specimens were positioned onto the carrier doubly to expose the upper and lower surface of the leaves. The specimens from the second analytical group were carefully enclosed in tissue freezing medium before fixation at low temperature. All samples were quickly plunged-frozen in solidified nitrogen (slash) at a temperature around $-210{ }^{\circ} \mathrm{C}$ and stored in liquid nitrogen for further processing. The first group of frozen samples was transferred directly to the tissue dryer (Edwards ETD4, Edwards High Vacuum International, UK) in cold gas nitrogen atmosphere and lyophilized overnight at $0.01 \mathrm{mbar}$ and $-30{ }^{\circ} \mathrm{C}$. After drying, the temperature of the specimen holder was gradually increased to achieve room temperature and the specimens removed.

The second group of samples was transferred to a cryostat chamber (CM1850 UV, Leica Microsystems, Germany), attached perpendicularly to the surface of cutting holders with freezing medium and trimmed until the internal structure of the leaves was exposed; normally $0.5 \mathrm{~mm}$ of the leaf was trimmed to visualize mesophyll and vascular tissues in scanning electron microscope (SEM). Then, the samples were transferred to the tissue dryer and lyophilized as mentioned above. Dried leaves were additionally attached to the aluminum specimen holders with current conductive carbon glue (SPI Supplies, USA), coated with a thin carbon layer $(\sim 15 \mathrm{~nm})$ in a JEE 4B evaporator (JEOL, Tokyo, Japan), and analyzed in a JSM-5410 scanning electron microscope (JEOL) with a NORAN 679ASES energy-dispersive spectrometer (EDS) equipped with a NORVAR thin-window (Noran Instruments, Middletown, WI, USA).

The EDS detector was positioned at take-off angle of $25^{\circ}$ and $30 \mathrm{~mm}$ away from the beam interaction volume (solid angle $0.0333 \mathrm{sr}$ ). Preliminary qualitative measurements to determine minimum detection limit for $\mathrm{Cr}$ were performed at $15 \mathrm{keV}$ accelerating voltage with the beam size of $80 \mathrm{~nm}$ and the probe current of $250 \mathrm{pA}$ as measured by means of the Faraday cup. It made analyses possible with the count rate of 2,000 quanta per second for the deadtime value of $\sim 20 \%$. Point analyses of mesophyll and vascular tissues were performed to ascertain the presence of chromium. Mapping of chromium distribution was performed for leaf regions with glands/hairs and stomata at the same geometry of the analytical system. However, to 

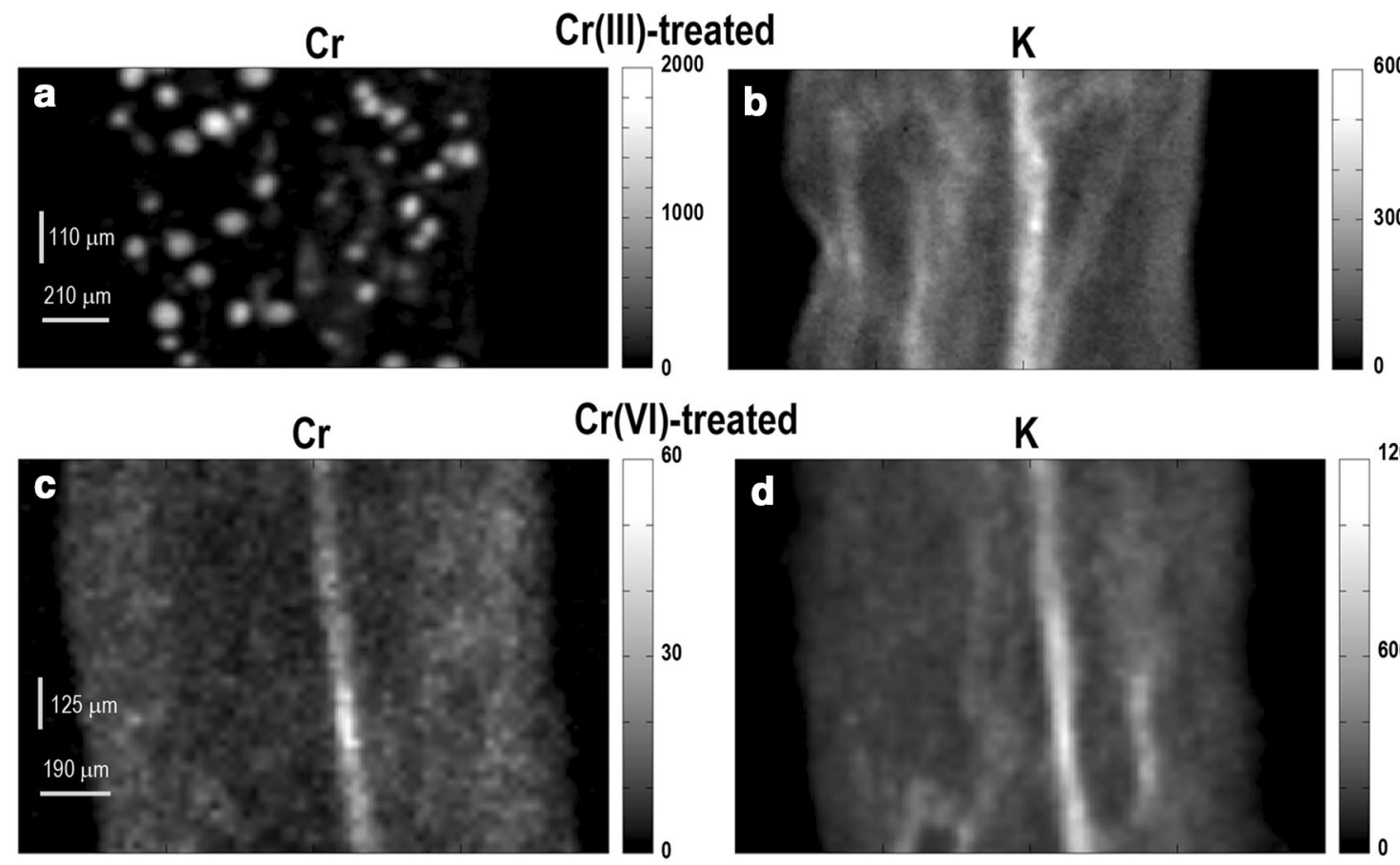

K

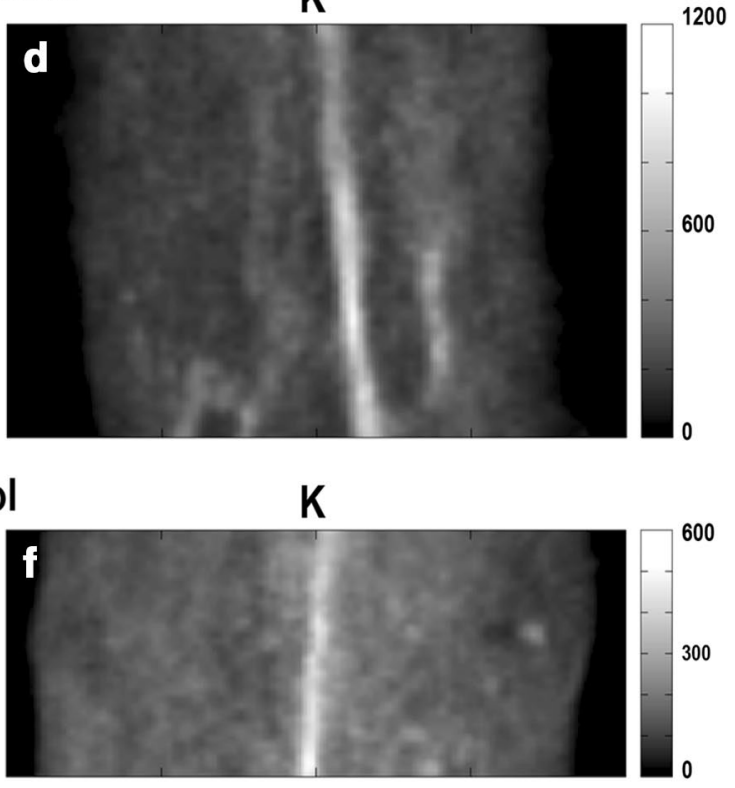

Fig. 1 Representative $\mu \mathrm{XRF}$ maps of chromium and potassium distribution in leaves of $\mathrm{Cr}(\mathrm{III})$ - and $\mathrm{Cr}(\mathrm{VI})$-treated as well as control group of C. cophocarpa. a $\mathrm{Cr}(\mathrm{III})$-treated leaf shows spot-like structures with high concentration of $\mathrm{Cr}$; $\mathbf{b} K$ distribution in $\mathrm{Cr}$ (III)-treated leaf that visualizes vascular bundle region; $\mathbf{c} \mathrm{Cr}(\mathrm{VI})$-treated leaf with $\mathrm{Cr}$ accumulated in the region of vascular bundle; $\mathbf{d} K$ distribution

Table 1 The median as well as minimal and maximal intensities of chromium characteristic X-rays emitted from leaves and stems not exposed to $\mathrm{Cr}$ (control) or exposed to $\mathrm{Cr}(\mathrm{III})$ or $\mathrm{Cr}(\mathrm{VI})$

\begin{tabular}{lcrrr}
\hline Specimen & & \multicolumn{3}{c}{ X-ray intensity (counts per second) } \\
\cline { 3 - 5 } & & Median & Min. & \multicolumn{1}{c}{ Max. } \\
\hline Cr(III) & \multirow{2}{*}{ Leaf } & $91.3(\mathrm{~d})$ & 1.7 & $1,802.5$ \\
Cr(VI) & & $4.7(\mathrm{~b})$ & 0.3 & 301.9 \\
Control & & $1.1(\mathrm{a})$ & 0.2 & 4.7 \\
Cr(III) & \multirow{2}{*}{ Stem } & $153.1(\mathrm{e})$ & 2.2 & $2,167.8$ \\
Cr(VI) & & $12.7(\mathrm{c})$ & 0.6 & 144.6 \\
Control & & $1.2(\mathrm{a})$ & 0.2 & 3.3 \\
\hline
\end{tabular}

The median value relates to X-ray intensity of fluorescence of $\mathrm{Cr}$ signal (counts per second) at the scanned area $\left(380 \mu \mathrm{m}^{-2}\right)$. The letters indicate statistically significant differences between treatments (Kruskal-Wallis non-parametric ANOVA and Dunn's test; $\alpha=0.05$ )

in $\mathrm{Cr}(\mathrm{VI})$-treated leaf that visualizes vascular bundle region; e the level of background intensity of X-rays characteristic for chromium emission in a leaf from the control group of plants; $\mathbf{f} K$ distribution in a leaf of the control group of plant that visualizes vascular bundle region. Grayscale indicates intensity of X-ray signal (cps) characteristic for chromium emission energy

obtain sufficient intensity of characteristic X-rays for chromium, the beam size of $130 \mathrm{~nm}$ was used. Thus, the probe current increased to $800 \mathrm{pA}$ and 4,500 counts per second were registered by EDS detector. Maps of Cr distribution were created for all experimental groups when 100 frames were accumulated by the system at the resolution of $512 \times 512$ pixels. Three samples of each experimental group were mapped.

Plant morphology examination—light microscopy

Fresh as well as ethanol-fixed (70\% ethanol solution) plant material was hand-sectioned with a razor-blade and examined under an Olympus BX60 (Olympus Corporation, USA) microscope equipped with differential interference contrast (DIC). Image-Pro PLUS ver.4.0 (Media 

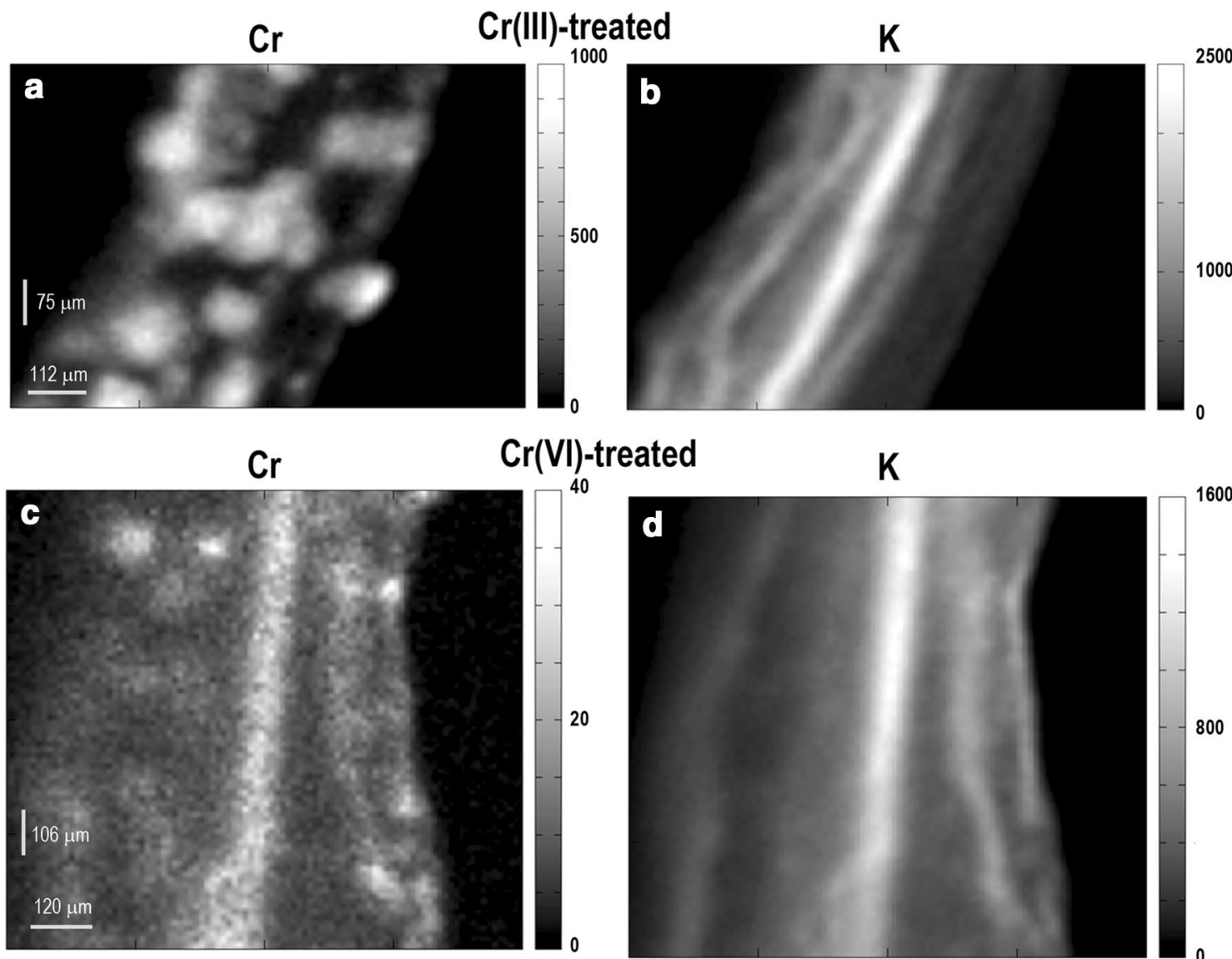

$\operatorname{Cr}(\mathrm{VI})$-treated

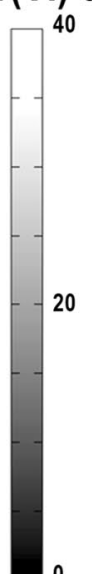

K
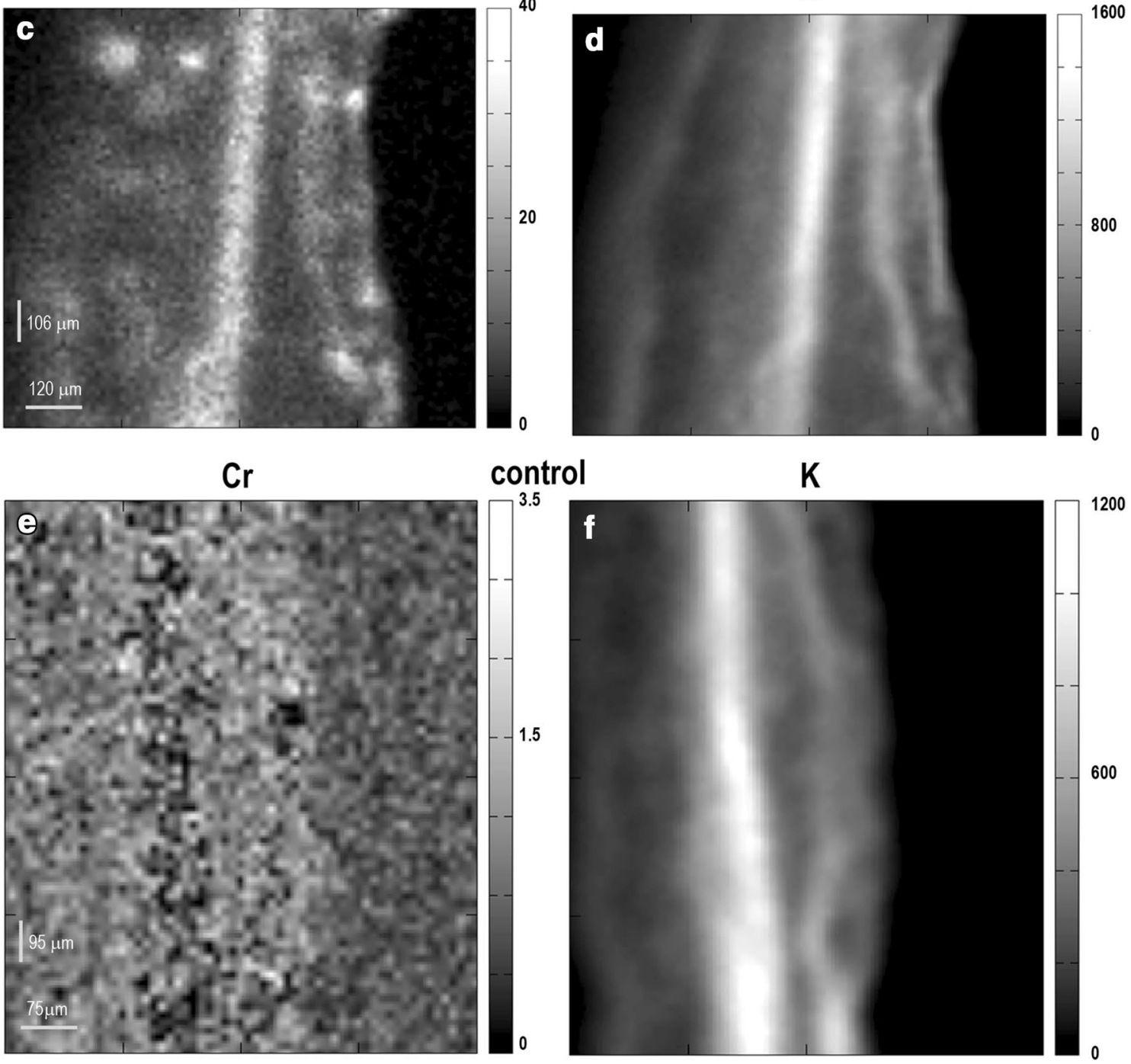

Fig. 2 Representative $\mu \mathrm{XRF}$ maps of chromium and potassium distribution in stems of $\mathrm{Cr}(\mathrm{III})$ - and $\mathrm{Cr}(\mathrm{VI})$-treated as well as control group of $C$. cophocarpa. a $\mathrm{Cr}(\mathrm{III})$-treated stem shows spot-like structures with high concentration of $\mathbf{C r}$; $\mathbf{b} K$ distribution in $\mathrm{Cr}$ (III)-treated stem that visualizes vascular bundle region; c $\mathrm{Cr}(\mathrm{VI})$-treated stem with $\mathrm{Cr}$ accumulated in the region of vascular bundle; $\mathbf{d} K$ distribu-

tion in $\mathrm{Cr}(\mathrm{VI})$-treated stem that visualizes vascular bundle region; $\mathbf{e}$ the level of background intensity of X-rays characteristic for chromium emission in a stem from the control group of plants; $\mathbf{f} K$ distribution in a stem of the control group of plant that visualizes vascular bundle region. Grayscales indicate intensity of X-ray signal (cps) characteristic for chromium emission energy 
Cybernetics Inc., Rockville, MD, USA) software was applied to measure distances between epidermal glands/ hairs in microscopic images. At least six independent leaves/stems were used for analysis.

\section{Statistics}

Three independent sets of experiments were conducted, with each set comprising several independent replicates. Results were statistically verified based on STATISTICA 10 software. The statistical tests were chosen according to the distribution of results. Non-parametric KruskalWallis/Mann-Whitney $U$ tests were applied to compare differences between objects. Following the rejection of null hypothesis, non-parametric multiple comparison test (Dunn's test) was performed to determine statistical significance of results at $\alpha=0.05$.

\section{Results}

We found significant differences in $\mathrm{Cr}$ distribution in both groups of Cr-treated plants, i.e., in the plants exposed to $\mathrm{Cr}(\mathrm{III})$ and $\mathrm{Cr}(\mathrm{VI})$. Figure 1a and $\mathrm{c}$ shows representative maps of $\mathrm{Cr}$ accumulated in leaves of $C$. cophocarpa. The plants treated with $\mathrm{Cr}$ (III) ions revealed spot-like chromium distribution (Fig. 1a), whereas leaves obtained from plants treated with $\mathrm{Cr}(\mathrm{VI})$ (Fig. 1c) showed homogeneous accumulation of $\mathrm{Cr}$ with significantly higher $\mathrm{Cr}$ deposition in the region of vascular tissue as indicated by $K$ pattern (Fig. 1b, d, f). The amount of $\mathrm{Cr}$ deposited in leaves in both Cr-treated plants differed significantly. The median X-ray intensity registered in $\mathrm{Cr}(\mathrm{III})$-treated leaves was around 19-times higher in relation to leaves from $\mathrm{Cr}(\mathrm{VI})$-treated plants (Table 1). There was no chromium registered in leaves obtained from the control group of plants (Fig. 1e).

Similarly to the leaves, mapping of stems from both groups of $\mathrm{Cr}(\mathrm{III})$-treated plants showed the presence of spot-like structures (Fig. 2a). The maps of $\mathrm{Cr}(\mathrm{VI})$-treated stems revealed Cr-rich areas (Fig. 2c) in the region of vascular bundle as indicated by $K$ (Fig. $2 \mathrm{~b}, \mathrm{~d}$, f). Similarly to the leaves, the median X-ray intensity of $\mathrm{Cr}$ signal in stems subjected to $\mathrm{Cr}(\mathrm{III})$ was 12 -times fold higher than in stems treated with $\mathrm{Cr}(\mathrm{VI})$. There was no chromium registered in stems obtained from the control group of plants (Fig. 2e).

In the next step of the study, distances between spotlike structures in leaves subjected to $\mathrm{Cr}$ (III) were measured on the basis of the $\mu \mathrm{XRF}$ maps and compared to distances obtained from light microscopic photographs of leaf surfaces (Fig. 3). The measurements were carried out only on flat surfaces of leaves because the geometry of stems (round in shape) made the measurements inaccurate. Many epidermal multi-cellular hairs were observed on

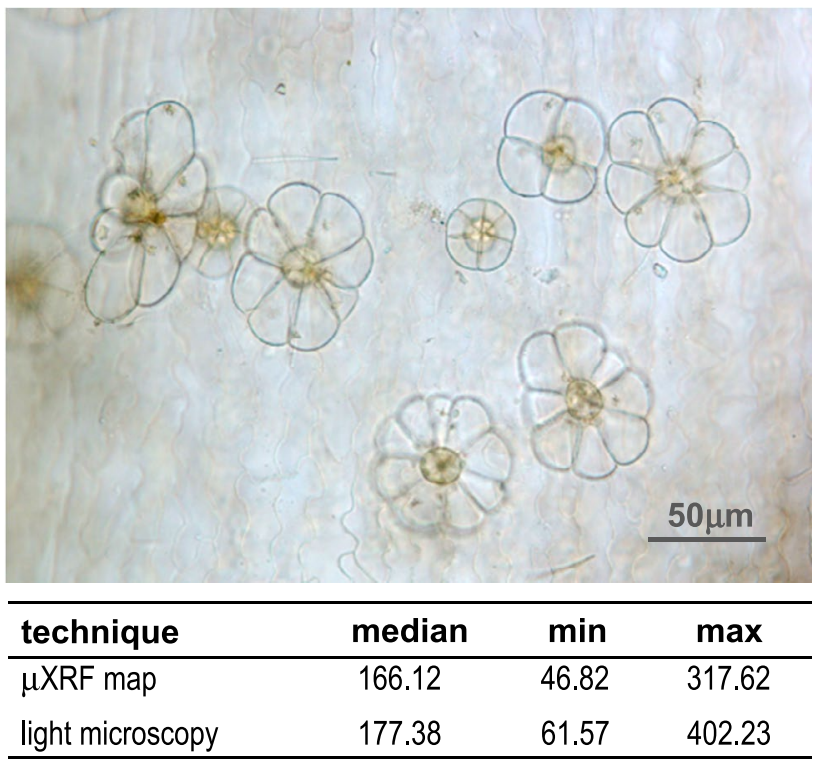

Fig. 3 Light microscopy photograph of $C$. cophocarpa leaf epidermis with well visible glands/hairs. The table represents median as well as minimal and maximal distances (in $\mu \mathrm{m}$ ) between epidermal glands/hairs measured on the basis of light micrographs and those measured between spot-like structures registered in $\mu$ XRF maps. No statistical differences between the values were found (Mann-Whitney $U$ test; $\alpha=0.05$ )

both lower and upper leaf epidermis (Fig. 3). The median distance between investigated structures observed in light microscope and in $\mu \mathrm{XRF}$ maps was not statistically different. It suggested that $\mathrm{Cr}$-contained spot-like structures were probably glands/hairs present on the upper or lower epidermis.

To confirm that glands/hairs are responsible for $\mathrm{Cr}$ accumulation in $\mathrm{Cr}$ (III)-treated plants, SEM equipped with X-ray energy-dispersive detector was applied. Concomitant SEM examination and X-ray analysis of $\mathrm{Cr}$ in C. cophocarpa stomata or glands/hairs confirmed the concentration of chromium below the limit of detection for EPXMA analysis $(<0.2$ mass\%) in the stomata cells (Fig. 4a) and its presence in glands/hairs when the plants were treated with chromium (Fig. 4b). It is noteworthy that the intensity of $\mathrm{Cr} \mathrm{X}$-rays emitted from glands/hairs of $\mathrm{Cr}(\mathrm{III})$-treated plants was significantly higher than the intensity detected for these structures of $\mathrm{Cr}(\mathrm{VI})$-treated plants (Fig. 4b). Analysis of $\mathrm{Cr}$ in the vascular bundles of leaves or stems by means of EPXMA did not show X-ray emission at the energy of $\mathrm{Cr}-\mathrm{K} \alpha$ line (Fig. $4 \mathrm{c}$; chromium concentration below the detection limit). Further SEM examination combined with $\mathrm{X}$-ray mapping of chromium revealed that indeed the element is accumulated in epidermal glands/hairs of leaves and stems from both Cr-treated groups of plants (Fig. 5). Cr was distributed homogeneously in epidermal glands/hairs of $\mathrm{Cr}(\mathrm{III})$-treated plants, 
Fig. 4 Representative spectra obtained after EPXMA of stomata cells (a), glands/hairs (b) and vascular bundle cell walls (c) using point mode analysis with concomitant imaging of structures of interest (inserts). The elements present in spectra are marked with their symbols. Analysis revealed chromium accumulation above the limit of detection $(<0.2$ mass $\%)$ only in glands/hairs of leaf or stem samples (b) but below this limit in stomata (a) and vascular bundle cells (c). Note the evident emission of chromium when analysis concerned glands/hairs derived from plants treated with $\mathrm{Cr}$ (III) solution and significantly lower intensity of chromium X-rays in the case of these structures from $\mathrm{Cr}(\mathrm{VI})$-treated plants. Bar $30 \mu \mathrm{m}$

but its accumulation in these structures of $\mathrm{Cr}(\mathrm{VI})$-treated group was heterogeneous. No chromium was detected in glands/hairs of the control group of plants.

\section{Discussion}

The methods used in this study enabled to determine $\mathrm{Cr}$ accumulation patterns in shoots of $C$. cophocarpa treated with two different chromium ions-at third and sixth oxidative states. A comparative analysis of $\mathrm{Cr}(\mathrm{III})$-treated plants by EPXMA and $\mu$ XRF demonstrated high deposition of $\mathrm{Cr}$ in epidermal glands/hairs localized on leaves and stems of the plant shoots. $\mathrm{Cr}$ in $\mathrm{Cr}$ (III)-treated plants was recorded solely in glands/hairs, and the element was not present in any other structures. On the other hand, $\mathrm{Cr}$ in $\mathrm{Cr}(\mathrm{VI})$-treated group of plants was rather found in vascular bundles. This phenomenon could be explained on the basis of physicochemical properties of $\mathrm{Cr}$. The ionic form of $\mathrm{Cr}$ in water solution depends on several factors, e.g., $\mathrm{pH}$, ionic strength, presence of complexing agents (organic matter) and redox potential (Eh). In the absence of complexing agents and $\mathrm{pH}$ range of 4-10, the dominant forms of $\mathrm{Cr}$ (III) are cations, e.g., $\mathrm{CrOH}^{2+}$ or $\mathrm{Cr}_{2}(\mathrm{OH})_{2}^{4+}$. $\mathrm{Cr}(\mathrm{III})$ in the cationic form passively diffuses across the cell wall and plasma membranes of cells, easily binding to hydroxyl, carboxyl, amide or sulfhydryl groups (Zayed and Terry 2003). Cr(III) exhibits strong affinity to organic ligands, like phenolic derivatives, what leads to formation of chromium-derived complexes (Kotaś and Stasicka 2000; Kyziol et al. 2006).

In general, many aquatic and amphibious plants have epidermal secretory hairs (trichomes/glands) on their shoots, e.g., Nymphaea (Lavid et al. 2001a; Lavid et al. 2001b), Myriophyllum (Godmaire and Nalewajko 1990), Aldrovanda (Lloyd 1942), Utricularia (Płachno and Świątek 2010), and also Callitriche (Erbar and Leins 2004). The hairs secrete substances into the external environment, but for example in Nymphaea, they may also be responsible for ion absorption from the surrounding water (Lavid et al. 2001a; Lüttge and Krapf 1969). It was also shown that in some aquatic plants the hairs immobilize toxic heavy
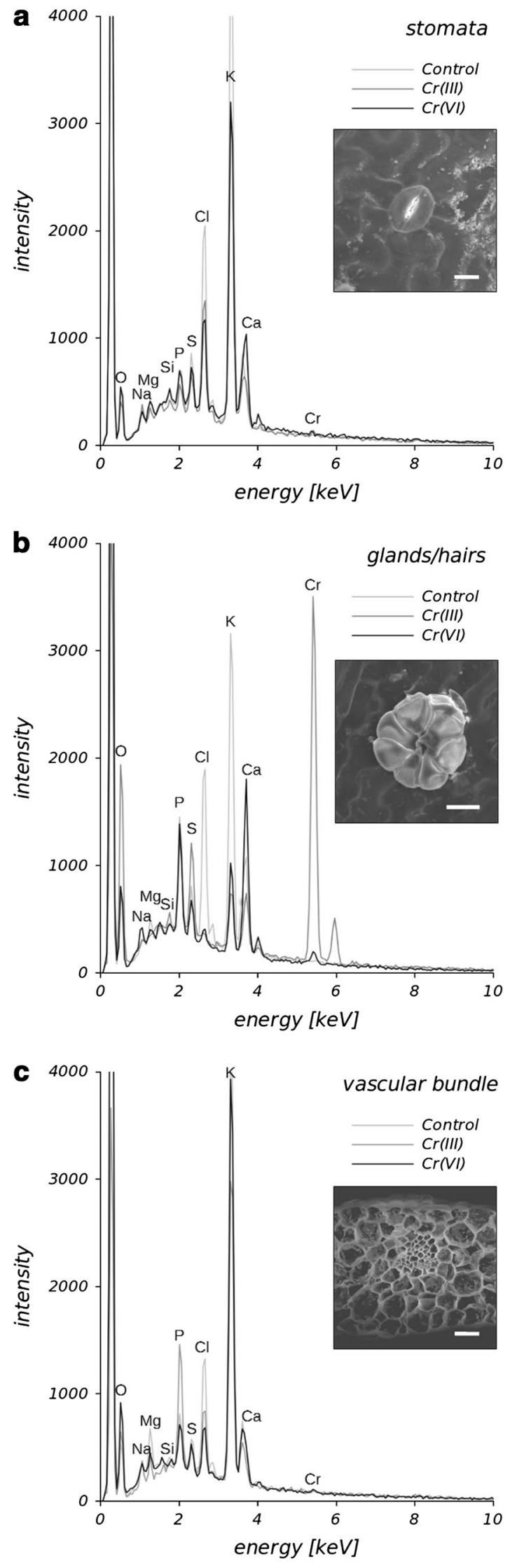


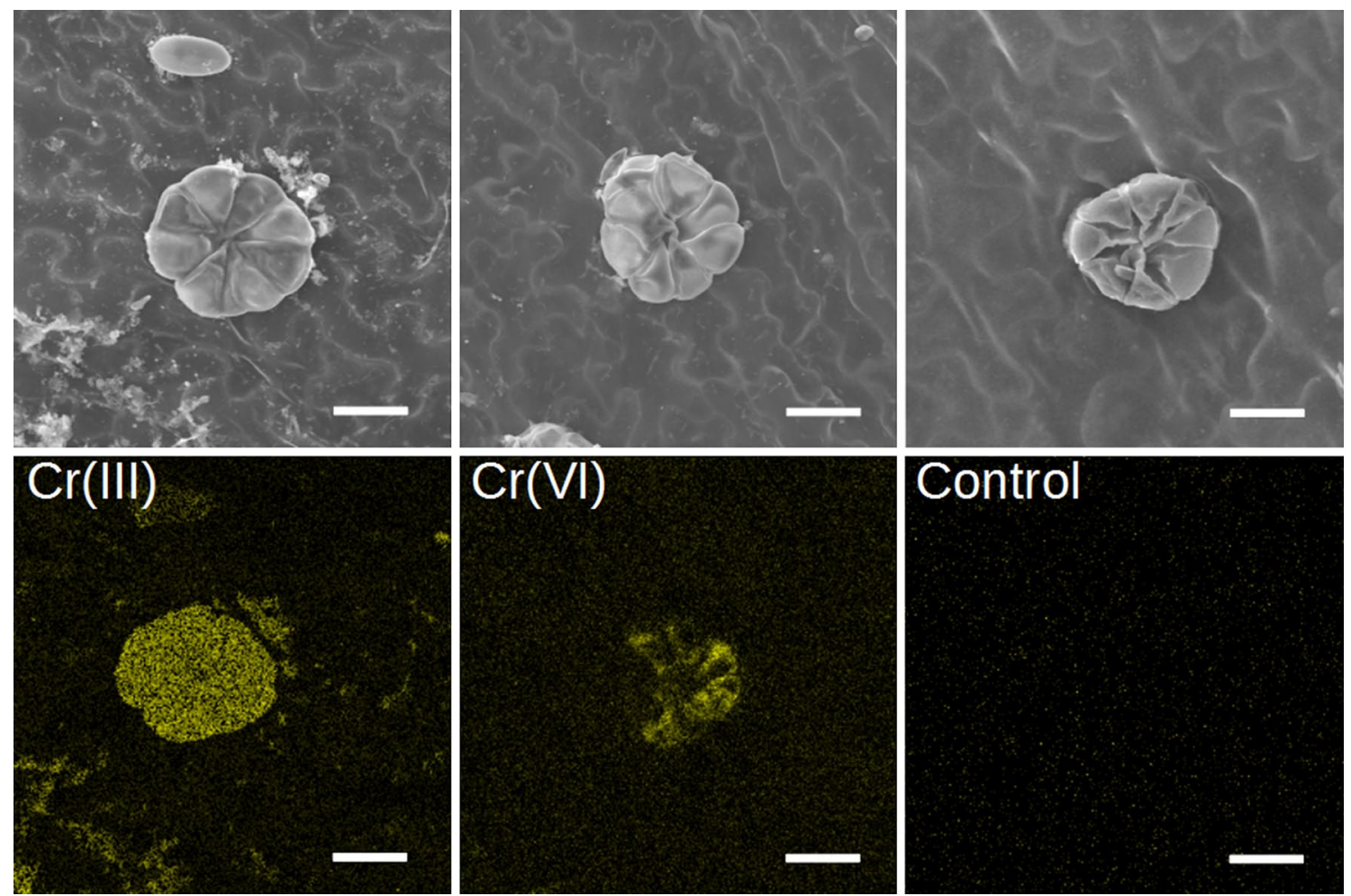

Fig. 5 Representative qualitative maps of chromium distribution in glands/hairs of Cr-treated and untreated (control) plants. Please note that the intensity of X-rays is not scaled for the presented images,

metals (Lavid et al. 2001a, b). It seems that glands/hairs of C. cophocarpa have a similar function. The study shows for the first time the possible role of epidermal hairs in $\mathrm{Cr}(\mathrm{III})$ accumulation in the leaves and stems of $C$. cophocarpa. Moreover, in the previous work by Augustynowicz et al. (2013b), it was revealed that the major pool of $\mathrm{Cr}(\mathrm{III})$ ions follows the strongest mechanism of metal binding to the organic matter in shoots of $C$. cophocarpa. $\mathrm{Cr}(\mathrm{III})$ bound in the form of chelates/complexes with surface organic groups. Thus, we postulate that $\mathrm{Cr}(\mathrm{III})$ is strongly accumulated only in the epidermal glands/hairs and these structures act as regulators of heavy metal ion exchange between plant tissues and water environment. In our opinion, the glands/hairs might block the transfer of $\mathrm{Cr}(\mathrm{III})$ ions to internal parts of shoots playing the role of natural barrier for chromium ions or other high atomic number elements (Lavid et al. 2001a, b).

In aquatic solutions, $\mathrm{Cr}(\mathrm{VI})$ exists as anion, mainly dichromate $\left(\mathrm{Cr}_{2} \mathrm{O}_{7}{ }^{2-}\right)$ or chromate $\left(\mathrm{CrO}_{4}{ }^{2-}\right)$. $\mathrm{Cr}(\mathrm{VI})$ is very mobile in the broad range of $\mathrm{pH}$, thus diverse mechanisms of $\mathrm{Cr}(\mathrm{VI}) / \mathrm{Cr}(\mathrm{III})$ transfer and accumulation in plants must be engaged. $\mathrm{Cr}(\mathrm{III})$ uptake is a passive process whereas $\mathrm{Cr}(\mathrm{VI})$ is transported under the control of sulfate (anionic) transporters (Appenroth et al. 2008; Kaszycki et al. 2005; Kotaś and Stasicka 2000). It seems that the easily mobile thus the maps cannot be compared to reveal differences in chromium content between the experimental groups. Bar $30 \mu \mathrm{m}$

$\mathrm{Cr}(\mathrm{VI})$ ions are transported in the plant via the vascular bundle, since we found chromium in this tissue when C. cophocarpa was treated with $\mathrm{Cr}(\mathrm{VI})$ ions. $\mathrm{Cr}(\mathrm{VI})$ is weakly bound to the organic matter of this plant. $34 \%$ of $\mathrm{Cr}(\mathrm{VI})$ ions was found in water soluble fraction, whereas $23 \%$ in mobile (easily exchangeable) fraction (Augustynowicz et al. 2013b). Since the sorption capacity of $\mathrm{Cr}(\mathrm{VI})$ is far less pronounced than of $\mathrm{Cr}(\mathrm{III})$, the anions can stay dissolved. Recently, Xue et al. (2010) found xylem- and phloem-based translocations of copper in Hydrilla verticillata. Similarly, intensive cadmium transport has been also observed in four emergent wetland species (Zhang et al. 2010). Still, detailed mechanisms of transport of heavy metal ions in the vascular system of macrophytes remain unknown (Malec et al. 2011).

Some amounts of $\mathrm{Cr}$ were also detected in glands/hairs of leaves and shoots of Callitriche when subjected to $\mathrm{Cr}(\mathrm{VI})$. Still, the level of $\mathrm{Cr}$ detected in leaves and stems of $\mathrm{Cr}(\mathrm{VI})$ treated $C$. cophocarpa was significantly lower than in $\mathrm{Cr}$ (III)treated plants. These results are consistent with the previous data obtained by means of inductively coupled plasma optical emission spectrometry (ICP-OES) (Augustynowicz et al. 2013b). However, the reported technique registers element concentrations only, without giving an insight into its distribution in tissues or cells. Lavid et al. (2001b) studied 
Nymphea exposed to $\mathrm{Cr}(\mathrm{VI})$ salts. They revealed that epidermal glands exhibited high $\mathrm{Cr}$ contents, which correlated with the increased amount of polyphenols: hydrolyzable tannins, gallic and tannic acids. It is probably the same strategy of chromium binding in C. cophocarpa glands/hairs. Recently, high concentrations of cinnamic acid-derivates as well as flavonoids were found in $C$. cophocarpa (Augustynowicz et al. 2014). It must be pointed out that chromium at the sixth oxidative state $\mathrm{Cr}(\mathrm{VI})$ could be reduced to the third oxidative state $\mathrm{Cr}(\mathrm{III})$, which is also widely considered as the main bioremediation strategy of $\mathrm{Cr}(\mathrm{VI})$ (Zayed and Terry 2003). Augustynowicz et al. (2013a) found internal $\mathrm{Cr}(\mathrm{VI})$ reduction in shoots of $C$. cophocarpa by means of the electron paramagnetic resonance spectroscopy ( $L$-band EPR). Reduction of $\mathrm{Cr}(\mathrm{VI})$ to $\mathrm{Cr}(\mathrm{III})$ may be a reason of some $\mathrm{Cr}$ accumulation in epidermal glands of $\mathrm{Cr}(\mathrm{VI})$-treated Nymphea plants (Lavid et al. 2001b) as well as in individual glands/ hairs of Callitriche stems and leaves.

Concluding, our study has shown different distribution patterns of $\mathrm{Cr}$ in C. cophocarpa shoots related to their oxidation state. $\mathrm{Cr}$ is exclusively accumulated in epidermal glands/hairs when $\mathrm{Cr}(\mathrm{III})$ is present in plant environment. However, in the case of $\mathrm{Cr}(\mathrm{VI})$ exposure, the element is principally found in the vascular bundles.

Acknowledgments We are grateful to Dr. Anna Kołton for her assistance during statistical analysis of the results and Dr. Anna Jurkiewicz for her helpful linguistic instructions. B.J. Płachno gratefully acknowledges the scholarship for Outstanding Young Scientists from the Minister of Science and Higher Education. The work was funded by the Grant DEC-2011/03/B/NZ9/00952 from the National Science Center, Poland. Electron microscopy studies and X-ray microanalysis were possible thanks to Scanning Electron Microscopy Laboratory of Biological and Geological Sciences at Faculty of Biology and Earth Sciences, Jagiellonian University.

Open Access This article is distributed under the terms of the Creative Commons Attribution License which permits any use, distribution, and reproduction in any medium, provided the original author(s) and the source are credited.

\section{References}

Appenroth KJ, Luther A, Jetschke G, Gabrys H (2008) Modification of chromate toxicity by sulphate in duckweeds (Lemnaceae). Aquat Toxicol 89:167-171

Augustynowicz J, Grosicki M, Hanus-Fajerska E, Lekka M, Waloszek A, Kołoczek H (2010) Chromium(VI) bioremediation by aquatic macrophyte Callitriche cophocarpa Sendtn. Chemosphere 79:1077-1083

Augustynowicz J, Kołton A, Baran A, Kostecka-Gugała A, Lasek W (2013a) Strategy of Cr detoxification by Callitriche cophocarpa. Cent Eur J Chem 11:295-303

Augustynowicz J, Kyzioł-Komosińska J, Smoleń S, Waloszek A (2013b) Study on Cr binding capacity to Callitriche cophocarpa in an aquatic environment. Arch Environ Contam Toxicol $64: 410-418$
Augustynowicz J, Długosz-Grochowska O, Kostecka-Gugała A, Leja M, Kruczek M, Świderski A (2014) Callitriche cophocarpa-a new rich source of active phenolic compounds. Cent Eur J Chem 12(4):519-527

Choo TP, Lee CK, Low KS, Hishamuddin O (2006) Accumulation of chromium (VI) form aqueous solutions using water lilies (Nymphaea spontanea). Chemosphere 62:961-967

Erbar C, Leins P (2004) Callitrichaceae. In: Kadereit JW (ed) Flowering plants dicotyledons. The families and genera of vascular plants VII. Springer, Berlin, pp 50-56

Favas PJC, Pratas J, Prasad MNV (2012) Accumulation of arsenic by aquatic plants in large-scale field conditions: opportunities for phytoremediation and bioindication. Sci Total Environ 433:390-397

Godmaire H, Nalewajko C (1990) Structure and development of secretory trichomes on Myriophyllum spicatum L. Aquat Bot 37:99-121

Goldstein JI, Lyman CE, Newbury DE, Lifshin E, Echlin P, Sawyer L, Joy DC, Michael JR (2003) Scanning electron microscopy and X-ray microanalysis. Kluwer Academic/Plenum Publishers, New York

Kabata-Pendias A, Mukherjee AB (2007) Trace elements from soil to human. Springer, Berlin, Heidelberg, New York

Kaszycki P, Gabryś H, Appenroth K-J, Jaglarz A, Sędziwy S, Walczak T, Koloczek H (2005) Exogenously applied sulphate as a tool to investigate transport and reduction of chromate in the duckweed Spirodela polyrhiza. Plant Cell Environ 28:260-268

Kotaś J, Stasicka Z (2000) Chromium occurrence in the environment and methods of its speciation. Environ Pollut 107:263-283

Kyziol J, Twardowska I, Schmitt-Kopplin Ph (2006) The role of humic substances in chromium sorption onto natural organic matter (peat). Chemosphere 63:1974-1982

Kyzioł-Komosińska J, Kukułka L (2008) Application of minerals cooccurring in brown coal deposits to removal of heavy metals from water and waste water. Works and studies, 75 (in Polish). Polish Academy of Sciences, Zabrze

Lavid N, Barkay Z, Tel-Or E (2001a) Accumulation of heavy metals in epidermal glands of the waterlily (Nymphaeaceae). Planta 212:313-322

Lavid N, Schwartz A, Yarden O, Tel-Or E (2001b) The involvement of polyphenols and peroxidase activities in heavy-metal accumulation by epidermal glands of the waterlily (Nymphaeaceae). Planta 212:323-331

Lloyd FE (1942) The carnivorous plants. Chronica Botanica, Waltham

Lüttge U, Krapf G (1969) Die Ultrastruktur der Nymphaea Hydropoten in Zusammenhang mit ihrer Funktion als Salz-transportierende Drüsen. Cytobiologie 1:121-131

Malec P, Myśliwa-Kurdziel B, Prasad MNV, Waloszek A, Strzałka K (2011) Role of aquatic macrophytes in biogeochemical cycling of heavy metals, relevance to soil-sediment continuum detoxification and ecosystem health. In: Sherameti I, Varma A (eds) Detoxification of heavy metals. Springer, Berlin, Heidelberg, pp 345-368

Mangabeira PA, Mielke MS, Arantes I, Dutruch L, da Silva D, Barbier F, de Almeida AAF, Oliveira AH, Severo MIG, Labejof L, Rocha DC, Rosa TS, Santana KB, Gavrilov KL, Galle P, LeviSetti R, Greinier-Loustalot MF (2006) Bioaccumulation of chromium in aquatic macrophyte Borreria scabiosoides Cham. \& Schltdl. Appl Surf Sci 252:6816-6819

Philbrick CT, Bernardello LM (1992) Taxonomic and geographic distribution of internal geitonogamy in new world Callitriche (Callitrichaceae). Am J Bot 79:887-890

Płachno BJ, Świątek P (2010) Unusual embryo structure in viviparous Utricularia nelumbifolia, with remarks on embryo evolution in genus Utricularia. Protoplasma 239:69-80

PN-EN ISO 17294-1:2007: water quality-application of inductively coupled plasma mass spectrometry (ICP-MS)—part 1: 
general guidelines. Polish Committee for Standardization, Warsaw, Poland

PN-EN ISO 9963-1:2001: water quality-determination of alkalinity-part 1: determination of total and composite alkalinity. Polish Committee for Standardization, Warsaw, Poland

PN-ISO 9297:1994: water quality—determination of chloride-silver nitrate titration with chromate indicator (Mohr's method). Polish Committee for Standardization, Warsaw, Poland

Pratas J, Favas P, Rodrigues N, Prasad M, Freitas H (2010) Phytofiltration of uranium by aquatic plants of Central Portugal. In: 4th WSEAS international conference on waste management, water pollution, air pollution, indoor climate, pp 77-80

Pratas J, Favas PJC, Paulo C, Rodrigues N, Prasad MNV (2012) Uranium accumulation by aquatic plants from uranium-contaminated water in Central Portugal. Int J Phytorem 14:221-234

Punshon T, Guerinot ML, Lanzirotti A (2009) Using synchrotron $\mathrm{X}$-ray fluorescence microprobes in the study of metal homeostasis in plants. Ann Bot 103:665-672

Qian J-H, Zayed A, Zhu Y-L, Yu M, Terry N (1999) Phytoaccumulation of trace elements by wetland plants: III. Uptake and accumulation of ten trace elements by twelve plant species. J Environ Qual 28:1448-1455

Rai UN, Sinha S, Tripathi RD, Chandra P (1995) Wastewater treatability potential of some aquatic macrophytes: removal of heavy metals. Ecol Eng 5:5-12

Regulation, 9 Nov 2011: Rozporządzenie Ministra Środowiska z dn. 9 listopada 2011 r. w sprawie sposobu klasyfikacji stanu jednolitych wód powierzchniowych oraz środowiskowych norm jakości dla substancji priorytetowych. Dziennik Ustaw nr 257, poz. 1545 (in Polish)

Saha R, Nandi R, Saha B (2011) Sources and toxicity of hexavalent chromium. Review. J Coord Chem 64:1782-1806

Schotsman HD (1972) Callitrichaceae. In: Tutin TG et al (eds) Flora Europaea. Cambridge University Press, Cambridge, pp 123-126

Thompson MV, Zwieniecki MA (2005) The role of potassium in long distance transport in plants. In: Holbrook NM, Zwieniecki MA (eds) Vascular transport in plants. Elsevier Academic Press, London, pp 221-240

Węgrzynek D, Mroczka R, Markowicz A, Chinea-Cano E, Bamford S (2008) Experimental evaluation of X-ray optics applied for microanalysis. X-Ray Spectrom 37:635-641

Wróbel P, Czyżycki M, Furman L, Kolasiński K, Lankosz M, Mrenca A, Samek L, Węgrzynek D (2012) LabVIEW control software for scanning micro-beam X-ray fluorescence spectrometer. Talanta 93:186-192

Xue P, Li G, Liu W, Yan C (2010) Copper uptake and translocation in submerged aquatic plant Hydrilla verticillata (L.f.) Royle. Chemosphere 81:1098-1103

Zayed AM, Terry N (2003) Chromium in the environment: factors affecting biological remediation. Plant Soil 249:139-156

Zhang X-H, Liu J, Huang H-T, Chen J, Zhu Y-N, Wang D-Q (2007) Chromium accumulation by the hyperaccumulator plant Leersia hexandra Swartz. Chemosphere 67:1138-1143

Zhang Z, Rengel Z, Meney K (2010) Cadmium accumulation and translocation in four emergent wetland species. Water Air Soil Pollut 212:239-249 